\title{
Полішук К.М.
}

аспірант кафедри української літератури Кіровоградський державний педагогічний університет імені В. Винниченка

\section{ДО ПИТАННЯ ПРО СИСТЕМНО-ЦІЛІСНУ ОРГАНІЗАЦІЮ ДРАМАТУРГІЧНОГО ТВОРУ}

\begin{abstract}
Системний аналіз досліджує поетику літературного твору, виявляючи ї̈ складові та взаємодію між ними. Змістові фактори набувають художнього вираження через відповідні виражально-впливові форми. Мета статті - окреслити поняття системно-цілісної організації драматургічного твору. На прикладі драматургічних творів Івана Тобілевича простежено яким чином усі елементи n'єси організовуються в систему. Отримані результати дослідження слугують підтрунтям до вивчення поетики драматургї Івана Тобілевича з погляду системного аналізу.
\end{abstract}

Ключові слова: система, системний аналіз, изілісність, оптимальна організація,системотворчий чинник, Іван Тобілевич.

Системный анализ исследует поэтику литературного произведения, выявляя ее составляюшие и взаимодействие между ними. Факторы содержания обретают художественное выражение через соответствуюшие выразительно-влиятельные формы. Цель статьи определить понятие системно-иелостной организации драматургического произведения. На примере драматургических произведений Ивана Тобилевича проследить каким образом все элементь пьесы организуются в систему. Полученнье результаты исследования служат основой к изучению поэтики драматургии Ивана Тобилевича с точки зрения системного анализа.

Ключевые слова: система, системный анализ, иелостность, оптимальная организация, системообразующий фактор, Иван Тобилевич.

System analysis explores the formal criteria of literary works, showing the interaction between the elements of the system. Content's factors that make up a high level of artistic literary work, providing artistry only if it's most comprehensive formal expression. The purpose of this article is to define the concept of system-integrated organization dramatic work. System analysis of a literary work searches factor of forming system and proves the system through the study of literary works between all elements together and bring them regarding the functionality of the main creative units (factor of forming system). On the example of dramatic works of Ivan Tobilevych we trace how all the 
elements in play organized in system. The results serve as a basis for the study of Ivan Tobilevych's drama in terms of system analysis. Analysis of systemintegrated organization of Tobilevych's drama is extremely important area of research.

Key words: system, systems analysis, integrity, optimal organization, factor of forming of the system, Ivan Tobilevych.

Методологія системного аналізу активно застосовується в точних та гуманітарних науках - математиці, фізиці, астрономії, інженерії, біології, лінгвістики, соціології. У літературознавстві системний аналіз, за словами Григорія Клочека, «найбільш досконалий $i$ найбільш точний спосіб аналізу» [Клочек 1989:138].

Мета статті - окреслити поняття системно-цілісної організації драматургічного твору, системотворчого чинника, а також на прикладі системоутворюючих чинників - головних творчих установок п'єс Івана Тобілевича - продемонструвати, як усі елементи системи організовуються в цілісність. Дослідження $є$ актуальним, адже аналіз системно-цілісної організації драматургічного твору фактично є аналізом його художності.

Із поняттям системної організації художнього твору тісно пов'язані поняття цілісність, гармонія, органічність («організм» літературного твору), оптимальна організація. Кожним із понять та питаннями їх взаємодії займалися багато дослідників, серед яких Б. Ейнхенбаум, В. Жирмунський, К. Станіславський, Л. Егрі, Г. Клочек та інші. Розкриття суті вищезгаданих понять, виявлення спільних рис та їх синтез веде до глибшого розуміння художнього твору як системи, особливостей функціонування, взаємодії та системної організації усіх елементів.

Для здійснення системного аналізу літературного твору перш за все слід з'ясувати з яких елементів та компонентів складається система твору фактично те, що складає його поетику. Дослідження складу поетики літературного твору має свою довгу і складну історію. Цією проблемою займалося багато дослідників, зокрема першими хто приділяв багато уваги 
питанню складу поетики літературного твору були М. Бахтін, Ю. Тинянов, В. Жирмунський. Склалася думка, що елементом, тобто неподільною одиницею літературного художньої системи літературного твору є прийом - засіб за допомогою якого досягається та чи інша мета. Кожен прийом виконує функцію, i саме за характером функцій та «способом генерування художнього смислу, прийоми групуються у мовні, сюжетні, композиційні, характеротворчі» [Клочек 1989:142]. Кожна із груп прийомів генерує художній смисл в той чи інший спосіб, виконує певне художнє завдання, певну функцію і «наступний крок» - за словами Г. Клочека - «полягає в тому, щуоб зрозуміти функцію кожної деталі як складника системи. Ідеться про осмислення тієї ролі, яку виконує кожна деталь у процесі функцііонування» [Клочек 2007:19].

Між групами найменших елементів системи літературного твору прийомами - існують системні зв’язки, і «таким чином утворюються системно організовані єдності, які щуодо всієї художньої системи твору є підсистемами - компонентами (мова твору, композиція, ритміка). Усі компоненти поетики також взаємоузгоджують свої зусилля на виконання художнього завдання» [Клочек 1989:142]. Художнє завдання у такому випадку розуміється як системоутворююча функція, іiї можна простежити i у кожному елементі, і у кожному компоненті.

Поняття системність та цілісність у багатьох дослідженнях часто ототожнюються. Дослідник І. Блауберг зауважує, що «y працях зі системної проблематики переважна більшість авторів не розрізняє изілісність $i$ системність (ияіле $i$ систему)» [Блауберг 1977]. Таке ототожнення хоча до деякої міри і є обгрунтованим, але все ж потребує деякого розрізнення, адже системний підхід є більш аналітичним - він конкретизує категорію цілого.

Стосовно аналізу цілісності у досліджені поетики твору Г. Клочек зазначає, що «критерї изілісності твору $\epsilon$ критеріями оизінки його 
художньої форми, тобто поетики» [Клочек 1989:138]. Таким чином поняття цілісності розуміється ще й в ототожненні із поняттям досконалості, довершеності, викінченості.

У своїй творчості митець перебуває у постійному виборі художніх засобів, прийомів, шляхів розгортання сюжету, героїв, композиції та усіх навіть найдрібніших елементів твору. I саме через вдалий чи не вдалий вибір «дрібних» елементів залежить буде чи не буде працювати механізм, буде чи не буде художній твір функціонувати як система, що генерує художню енергію. Оптимальна організація твору передбачає перебування автора твору у ситуації постійного вибору мікро- і макрокомпозиційних вирішень, героїв, навіть вибір слів, які найточніше передадуть авторську думку. Проблему організації художнього тексту та вибору художніх засобів зустрічаємо і у Льва Толстого: «із тисячі думок, що обертаються в голові письменника, повинна бути вибрана тільки одна думка, а з тисячі варіантів, де вона може бути втілена, треба знайти тільки один найбільш імовірний для неї варіант» [ЛЭ 1929:105-106].

Стосовно оптимальної організації В. Бєлінський зазначав, що «будьякий твір мистецтвва тільки тому художній, щео створений за законом необхідності, щчо в ньому нема нічого випадкового, щцо в ньому жодне слово, жоден звук, жоден штрих не може бути замінений іншим звуком, іншим словом, іншим шттрихом» [Белинский 1948:438]. Саме через правильне розташування кожного 3 елементів, через відсутність непотрібних та присутність усіх необхідних складових літературний твір працює як система.

Оптимальна організація також співвідноситься із поняттям міри. Обираючи певні художні засоби митець не лише відсіює непотрібні і лишає з багатьох варіантів єдині можливі рішення, а ще й відповідає за їх кількісну та якісну наповненість. Надмір або недостатність призводять до 
того, що художній твір не може функціонувати як система, тому міра $є$ важливою категорією.

Тісно із поняттям оптимальної організації співвідноситься поняття гармонії, яке у літературознавстві зустрічається досить рідко, тоді як при аналізі, наприклад, музичних творів та архітектури ця категорія $\epsilon$ популярною. За словами Г. Клочека, гармонія характеризується «поняттями зв'язку, повноти, симетрії, контрасту, міри, закономірності, урівноваженості, упорядкованості, пропоричї $i$ диспропориії» [Клочек 1989:152]. Відчуття гармонії для митця є важливим фактором творення художності твору. Зокрема відчуття гармонії до деякої міри $\epsilon$ визначальним фактором у композиційній побудові твору.

Торкається питання гармонії Лайош Егрі у книжці «Мистецтво драматургії», тісно переплітаючи із гармонією поняття «оркестрування», тобто злагодженості між дійовими особами п’єси. Егрі стверджує, що правильне оркестрування - підбір дійових осіб із різними поглядами, естетичними, етичними, та іншими переконаннями, різними темпераментами - $є$ головною передумовою появи конфлікту в драматургічному творі. У такому разі гармонія твору будується на протиставленні (добро - зло, життя - смерть, боягузтво - безстрашність тощо).

До складу системи входять не хаотичні та випадкові елементи, а такі, які виконують свою певну функцію для досягнення роботи системи. У добре організованій системі відсутні випадкові та зайві елементи - адже тоді б система не могла функціонувати. Також існує ієрархія всередині системи у якій кожен елемент займає своє, правильне місце.

Таким чином до поняття системи додаються поняття цілісності, оптимальної організації, органічності. Системний аналіз літературного твору покликаний на пошук системотворчого чинника, а також доведення функціонування системи літературного твору через дослідження взаємодії 
усіх елементів між собою та доведення їх функціональності стосовно головної творчої установки (надідеї) - системоутворюючого чинника літературного твору.

Питання цілісності власне драматургічного тексту та вистави як його сценічного втілення глибоко розроблене у книзі К. Станіславського «Робота актора над собою». Автор аргументує свою позицію цілісності розумінням того, що вистава і п’єса мають певний чинник, який організовує їх як системи. Головним для системно-цілісної організації драматургічного твору та вистави, за Станіславським, $є$ поняття надідеї (надзавдання, фактично - головної творчої установки).

Станіславський відшукує головні системоутворюючі чинники, відповідаючи на питання куди вести виставу? - «до головного ц̧ентра, до столиці, до серияя n’єси, до основної мети, заради якої поет писав свій твір, а артист творив одну з його ролей» [Станіславський 1953:354]. Цю мету Станіславський називає надзавданням (надідеєю) - воно i $\epsilon$ системоутворюючим чинником, адже «притягує до себе всі без винятку задачі $i$ викликає творче стремління рушїв психічного життя та елементів самопочуття артисто-ролі. [...] Все щзо відбувається в n’єсі, всі ї̈ окремі великі або малі задачі, всі творчі помисли та дї артиста, аналогічні з роллю, прагнуть виконати надзавдання п’єси» [Станіславський 1953:355].

Таким чином, К. Станіславський стосовно системності драматургічного твору робить висновок, що п’єса (або вистава) як система складається із окремих елементів, кожен із яких має свої завдання, які підпорядковуються головному - надзавданню. Отже, надзавдання п’єси, вистави, ролі є необхідним елементом який організовує усі дію п’єси, тобто є системотворчим чинником.

Головний системотворчий чинник, за Лайошом Егрі, - посилка - «ųе сила, яка стоїть за всім, щзо ми робимо» [Егрі]. В понятті «посилка» Егрі 
сконцентровує поняття «тема, тезис, ключова ідея, цүентральна ідея, цүіль, сила, яка рухає, сюжет, фабула, основне переживання» [Егрі]. Термін «посилка», за Егрі, інтегрує в собі ці поняття, значно спрощуючи термінологічний апарат дослідження, водночас його поглиблюючи. Важливе місце в теорії Егрі відведене пошуку способів формулювання посилки: «у кожної хорошої n’єси має бути чітко викладена посилка. Ї̈̈ можна викладати декількома способами, але думка має залишатися тією самою» [Егрі]. Егрі в своїй теорії розуміє системотворчий чинник у вигляді головної ідеї (посилки), тобто того, що хоче донести до публіки автор, i підпорядковує досягненню своєї мети кожний прийом, елемент драматургічного твору.

В теорії Лайоша Егрі системотворчий чинник формулюється таким чином: «посилка складається з трьох частин, кожна з яких необхідна для гарної п’єси. Розгляньмо посилку «Скупість веде до розорення». Периа частина передбачає характер - характер скупого. Друга частина - «веде до» - передбачає конфлікт, і третя частина «розорення» - передбачає кінещь n'єси» [Егрі]. Бачимо, що у цьому понятті поєднано і конфлікт, i характер, і розв’язку - основні та визначальні елементи п’єси.

Найталановитіші митці особливо чутливі до цілісності літературного твору. Простежити ставлення Івана Тобілевича до системно-цілісної організації драматургічного твору нам допомагає інформація, експлікована iз листів драматурга як досить цінного джерела метапоетичної інформації. Іван Тобілевич розумів момент оптимізації тексту, а отже і його системноцілісну природу, як один із фундаментальних чинників його художньої сили: «нічого випадкового не повинно бути в n’єсі; кожна подія має бути тісно пов'язана з іншою, щоб було видно причинний зв'язок» [Спогади 1987:77]. У цій лаконічній та інформативній фразі закладено розуміння Тобілевичем головних ознак цілісності, системності, причиннонаслідковості, оптимальної організації - провідних ознак художності 
драматургічного твору. Ці слова є одним із ключів у дослідженні поетики Тобілевича. Важливим $є$ той факт, що сам Іван Тобілевич вважав драматургічний текст системною цілісністю, а отже і мав певні уявлення про чинники, які цю систему організовують. Це дає усі підстави розглядати драматургічне мистецтво Тобілевича із позицій системного аналізу, додається впевненості у тому, що цей шлях вірний.

Аналіз системотворчих чинників п’єс Івана Тобілевича $є$ важливою для розуміння системно-цілісної організації його драматургії. За системоутворюючий чинник вважаємо головну творчу установку - той творчий результат, який автор хотів досягти своїм твором, ту думку чи ідею, яку він хотів донести до реципієнта. Пошук та аналіз системотутворюючих чинників фактично означає дослідження системноцілісної організації.

Пошуки системотворчих чинників у драмах Івана Тобілевича можна здійснювати різними способами. По-перше, спробувати знайти в метапоетичному матеріалі згадки про творчі задуми, історії написання тих чи інших драм, дізнатися про головну ідею твору не опосередковано від автора. По-друге, можна скористатися дослідженнями інших науковців і простежити той фактор, який вони виділяють визначальним у тому чи іншому творі. По-третє, самому дослідити текст, побачити системні зв’язки, сформулювати системотворчий чинник. Всі ці підходи досліднику необхідно інтегрувати.

У листах Тобілевича зустрічаємо достатню кількість згадок про власні драми, але стосуються ці згадки переважно тих п’єс, які були заборонені цензурою до постановки. Системотворчий чинник п’єси «Хазяїн» сам автор фактично сформулював у листі до сина: “”Хазяйн” же зла сатира на чоловічу любов до стяжання, без жодної іншої мети. Стяжання для стяжання!» [Карпенко-Карий (том 3) 1985:334]. Саме «стяжання для стягання» і організовує усю дію п'єси - саме цією ідеєю 
«хазяйнування» i збагачення 3 ціллю збагачення просякнуто кожну дію драми. Головна дійова особа - Пузир - від початку п’єси і до кінця чи не кожним своїм словом і вчинком доводить головну ідею автора. Тема «хазяйства» розкривається і через інших персонажів, зокрема Феногена.

У п’єсі «Сто тисяч» головну творчу установку (або точніше посилку, за Егрі) можна сформулювати наступним чином: «Прагнення легкої наживи веде до розорення». Всередині дії махінація Герасима Калитки із фальшивими грошима, які $\epsilon$, на перший погляд, легкою наживою. Але головний герой сам стає об'єктом махінації. У результати розв'язання конфлікту - втрачені гроші і втрачений шанс придбати омріяну Калиткою землю. Кожна дія, кожна фраза у п’єсі веде до розкриття і доведення цієї ідеї. Вважаємо, що грунтовне дослідження методом повільного читання того, як творча установка п’єси проникає та організовує кожен її елемент $є$ вельми перспективним.

Системоутворюючим чинником іноді може виступати назва п'єси, адже вона $є$ фактично іï квінтесенцією. Одною із варіантів назви п’єси «Бурлака» була назва «Чабан». Вона найкраще відповідає темі, увиразнює та поглиблює іï, а отже у певній мірі $є$ тим чинником, який організовує дію. Старшина у драмі постає в образі вовка, котрий обманює громаду (отару овець) - «украв громадські гроші та й баришуєш з жидом; підлогом хотів парубка віддать у москалі, щэоб женитися на його дівчині; підлогом наділи у людей поодбирав; підлогом хочеш і мене запакувать» [КарпенкоКарий (том 1) 1985:54]. Але з'являється захисник (чабан) - Опанас Зінченко, який вже колись був старшиною, i, до того ж, чабаном. Він намагається захистити громаду від вовка, повести іiі у правильному напрямку, до того ж врятувати невинного Олексу, який потрапив у зуби до «вовка». Порівняння Опанаса із чабаном, старшину із вовком, а громаду із вівцями особливо простежуються наприкінці п'єси у таких словах Опанаса: «досада тільки їсть мою душу, як згадаю овець, котрих поїдом 
їсть Михайло, а вони ще й прислужують йому» [Карпенко-Карий (том 1) 1985:59], «хотів овець оборонить від вовка, а вони самі йому в зуби лізуть!» [Карпенко-Карий (том 1) 1985:55]. Образ чабана, до всього того, має певне біблійне прочитання, що увиразнюється саме цим варіантом титулу.

Назва драми «Не так пани, як підпанки» не лише підкреслює головний зміст драми, а $\epsilon$, фактично, головною творчою установкою автора - показати, що в бідах простого народу (у цьому випадку кріпаків) не завжди винні пани, адже вони навіть не відають про те, що роблять їхні служники. Це призводить до розуміння, що повнота влади не завжди належить тому, хто знаходиться на вищій ступені іiі ієрархії - часто люди із дрібними посадами мають більше впливовості за найвище начальство.

Отже, розуміючи особливості складу поетики літературного твору, виокремивши всі його елементи та компоненти, можна розглядати художній твір як систему 3 позицій системно-цілісної організації (системного аналізу). Системний аналіз літературного твору покликаний на пошук системотворчого чинника, а також доведення функціонування системи літературного твору через дослідження взаємодії усіх елементів між собою та доведення їх функціональності стосовно системоутворюючого чинника літературного твору. В теорії Л. Егрі системотворчим чинником виступає поняття посилки. Воно включає в себе поняття конфлікту та характеру. Ми за системотворчий чинник драматургічного твору вважаємо його головну установку, тобто той художній результат, який автор очікує отримати. Аналіз системутворюючого чинника, корелятивності елементів та компонентів драматургічного твору, їх функціональність дозволяє побачити драматургічний твір як цілісно організовану систему. Дослідження системно-цілісної організації драматургії Івана Тобілевича вважаємо вельми перспективним. 


\section{БІБЛІОГРАФІЯ}

Белинский 1948 - Белинский В. Полное собрание починений / В. Белинский - М., 1948. - т 2. - С. 438

Блауберг 1977 - Блауберг И. Целостность и системность // Системные исследования : Ежегодник. - М., 1977. - С 5-28

Егри - Егри Лайош. Искусство драматургии [Електронний ресурс]. Режим доступу: http://teatre.com.ua/upload/all/lib/iskustvo_dramaturgii.pdf

Карпенко-Карий (том 1) 1985 - Карпенко-Карий I. (Тобілевич I. К.) Твори: В 3-х т. Т.1. Драматичні твори, листи, статті / Упоряд. П. М. Киричка та Л. Ф. Стеценка. - К. : Дніпро, 1985. - 439 с.

Карпенко-Карий (том 3) 1985 - Карпенко-Карий І. (Тобілевич I. К.) Твори: В 3-х т. Т. 3. Драматичні твори, листи, статті / Упоряд. П. М. Киричка та Л. Ф. Стеценка. - К. : Дніпро, 1985. - 373 с.

Клочек 1989 - Клочек Г. У світлі вічних критеріїв (Про систему критеріїв оцінки літературного твору) / Григорій Клочек. - К.: Дніпро, 1989. - 221 c.

Клочек 2007 - Клочек Г. Енергія художнього слова. Збірник статей / Григорій Клочек. - Кіровоград: РВВ КДПУ ім. В. Винниченка, 2007. $448 \mathrm{c.}$

ЛЭ 1929 - Литературная энциклопедия в 11 томах. Том 1. - М., 1929. - C. 105-106.

Спогади 1987 - Спогади про Івана Карпенка-Карого: Збірник / Упорядкування Р. Я. Пилипчука. - К. : Мистецтво, 1987. - 183 с.

Станіславський 1958 - Станіславський К. Робота актора над собою / Костянтин Станіславський. - К. : «Мистецтво». - 1953. - 671 с. 